\title{
En mann i 30 -årene med feber etter safari i Sør-Afrika
}

\author{
En mann i 30-årene ble innlagt i sykehus med feber og mistenkt infek- \\ sjon. Årsaken til symptomene ble initialt vurdert å være en ordinær \\ pneumoni, men én diagnostisk test skulle vise seg å få betydning for \\ den videre oppfølgingen av pasienten.
}

Lars Christian Bråten

l.c.h.braten@studmed.uio.no Dag Henrik Reikvam

Infeksjonsmedisinsk avdeling

Oslo universitetssykehus, Ullevål
En tidligere frisk mann i 30-årene ble innlagt i sykehus etter at han hadde følt seg syk og hatt høy feber en uke. Han var født og oppvokst i Norge, brukte ingen faste medisiner og hadde aldri før vært innlagt $i$ sykehus. 19 dager før symptomdebut hadde han kommet hjem fra en ukes opphold i Sør-Afrika, hvor han blant annet hadde deltatt på safari. Han hadde ikke brukt malariaprofylakse og hadde fått «noen myggestikk».

Ved ankomst sykehuset følte han seg slapp. Han hadde hatt til sammen 1-2 tømminger med løs avføring de siste dagene. Det var for øvrig ingen fokale symptomer, spesifikt ingen luft- eller urinveissymptomer. Ved undersøkelse var det et blodtrykk på 135/85 mm Hg, regelmessig puls på 100 slag/min, temperaturen var $40,0^{\circ} \mathrm{C}$, respirasjonsfrekvensen 20 per minutt og perifer oksygenmetning $100 \%$. Det var ingen utslett eller tegn på insektbitt eller -stikk. Han var ikke nakkestiv. Somatiske undersøkelse for øvrig var også upåfallende.

Biokjemiske prøver viste leukocytter 9,0 . $10 \% / \mathrm{l}\left(3,5-10 \cdot 10^{\%} / \mathrm{l}\right)$, lymfocytter $0,9 \cdot 10^{9} / \mathrm{l}$ $\left(1,5-4,0 \cdot 10^{9} / \mathrm{l}\right)$, monocytter $1,1 \cdot 10^{9} / \mathrm{l}$ $\left(0,2-0,8 \cdot 10^{9} / \mathrm{l}\right)$, trombocytter $137 \cdot 10^{\%} / \mathrm{l}$ $\left(145-390 \cdot 10^{9} / \mathrm{l}\right)$, hemoglobin $13,2 \mathrm{~g} / 100 \mathrm{ml}$ (13,4-17,0 g/100 ml), LD $301 \mathrm{U} / \mathrm{l}(105-205 \mathrm{U} / \mathrm{l})$, CRP $330 \mathrm{mg} / \mathrm{l}(0-4 \mathrm{mg} / \mathrm{l})$ og Na $130 \mathrm{mmol} / \mathrm{l}$ (137-145 mmol/l). Øvrig leukocyttdifferensialtelling, leverparametere og nyrefunksjonsprøver var innenfor referanseområdene. EKG-undersøkelse viste normal sinusrytme. Røntgen thorax viste infiltrat $i$ høyre underlapp, forenlig med infeksjon.

De differensialdiagnostiske mulighetene er mange med feber av en ukes varighet - og ytterligere utvidet $\mathrm{i}$ lys av pasientens nylige opphold i Sør-Afrika. En grundig klinisk undersøkelse er i en slik forbindelse essensiell, selv om det ikke er uvanlig at man står igjen med et uklart fokus for antatt infeksjon. Høyt CRP-nivå taler for bakteriell eller parasittær årsak.

En viktig differensialdiagnose som bør utelukkes tidlig er malaria, ettersom dette kan ha alvorlig prognose dersom man ikke kommer i gang med behandling tidlig i for- løpet (1). En mer detaljert reiseanamnese er viktig, da det kun er i noen få provinser i den nordøstlige delen av Sør-Afrika man er utsatt for malariasmitte (2). Pasienten hadde ikke brukt malariaprofylakse og hadde fått myggestikk. 19 dagers inkubasjonstid er lenge, men kan på ingen måte utelukke malaria (1). Det er viktig å være klar over at malaria initialt kan imitere andre infeksjonssykdommer, som gastroenteritt og pneumoni.

Tyfoidfeber er også en differensialdiagnose det er viktig å vurdere tidlig, da forsinket oppstart av behandling kan gi dårligere prognose. Infeksjon med Salmonella typhi/paratyphi kan gi lite gastrointestinale symptomer tidlig i forløpet (3). Hyponatremi og pneumonisk infiltrat hos vår pasient retter tankene mot atypiske pneumonier, og da særlig legionella. Typisk kan man smittes av Legionella ved hotellopphold i utlandet (4). Andre differensialdiagnoser er blant annet denguefeber, afrikansk flåttbittfeber og andre rickettsioser (5).

Blodutstryk med tykk og tynn dråpe ble undersøkt, uten funn av malariaparasitter. Hurtigtest på fullblod for Plasmodium falciparum var også negativ. Han hadde ved nærmere anamnese ikke oppholdt seg i områder i Sør-Afrika med endemisk malariasmitte. Denguefeber-lgM-og -antigenhurtigtest på fullblod var negativ. Det ble sikret dyrkingsprøver av blod, urin, nesesekret og avføring. Det ble tatt penselprøve fra anus med tanke på Salmonella typhi/paratyphi. Hivtest var negativ. Man oppfattet tilstanden som sannsynlig pneumoni og valgte å starte empirisk antibiotikabehandling med penicillin intravenøst med tillegg av ciprofloksacin intravenøst for å dekke for atypisk pneumoni. Hurtigtest på legionella- og pneumokokkantigen $i$ urin var begge negative.

Pasienten ble overflyttet fra akuttmedisinsk mottak til infeksjonsmedisinsk avdeling. Det var i mottaket tatt dyp neseprøve for nukleinsyrepåvisning (PCR) av virale luftveisagenser, Chlamydia pneumoniae, Mycoplasma pneumoniae og Bordetella pertussis, som alle var negative. Man valgte derfor 
på dag 2 å seponere ciprofloksacin og fortsette med penicillin i monoterapi. Grunnet diagnostisk usikkerhet ble utredningen på dag 2 utvidet med CT thorax i lungeemboliprotokoll. Denne viste pneumonisk infiltrat $i$ høyre underlapp, men normale lungekar uten tegn til embolisme (fig 1). CRP-nivået falt langsomt, men pasientens allmenntilstand ble gradvis bedre, temperatur $37,8^{\circ} \mathrm{C}$ på dag 4. Samme dag ble blodkulturene som var tatt ved innkomst, besvart med «ingen vekst».

På bakgrunn av kliniske funn og laboratorieog radiologifunn vurderte man at tilstanden sannsynligvis skyldtes pneumoni. Pasienten hadde dog ingen luftveissymptomer. Eldre med pneumoni kan ha beskjedne symptomer fra luftveiene, men for en person i pasientens alder er dette uvanlig (6). Generelt er det viktig at man ved radiologiske lungeinfiltrater og kliniske symptomer som er lite karakteristiske for pneumoni vurderer andre årsaker til infiltrat, som lungeembolisme, lungeødem, tumor og andre ikke-infeksiøse inflammasjonssykdommer.

CT thorax viste ingen lungeembolisme og ga heller ingen pekepinn om andre årsaker til infiltratet. Nukleinsyreanalyse fra dyp neseprøve eller antigentester $\mathrm{i}$ urin ga ingen holdepunkter for hva som kunne være aktuell agens. Radiologisk er det ikke mulig å skille forskjellige mikrobielle agenser ved pneumoni $(7,8)$. Biokjemisk var det holdepunkter for bakteriell agens, siden det var høyt CRPnivå.

Pneumokokkpneumoni gir oftest leukocytose og granulocytose (9). Dyrking av ekspektorat kan bidra til å si noe om mikroben ved pneumoni, men har begrenset nytte ved samfunnservervet pneumoni (10). Bronkoskopi med prøver fra bronkoalveolær lavage (BAL) kan i noen tilfeller være nyttig, særlig dersom man mistenker infeksjon med Pneumocystis jiroveci eller tuberkulose. Vår pasient hadde ingen kjent immunsvikt eller andre risikofaktorer for en pneumocystisinfeksjon. Tuberkulose var lite sannsynlig sett i lys av alder, etnisitet og lokalisering av lungeinfiltratet, men kunne ikke utelukkes. Pasienter med tuberkulose vil ikke respondere på penicillinbehandling. Selv om kinoloner vil kunne virke på tuberkulose (11), var dette en lite sannsynlig diagnose hos vår pasient.

Man valgte å fortsette behandlingen med penicillin i monoterapi og se an effekten av denne. De neste par dagene ble pasienten langsomt bedre. Han var afebril dag 4 og hadde et CRP-nivå på $157 \mathrm{mg} / \mathrm{l}$ dag 5. Det var da ikke indikasjon for å gå videre med BALundersøkelser.

Det ble vurdert at sykdomsbildet ikke fremsto som en vanlig lungebetennelse på grunn av kombinasjonen av stort radiologisk infiltrat og høyt CRP-nivå sammen med kun lett redusert allmenntilstand, ingen fokale symptomer og langsom respons på antibiotika.

Rutinemessig leter man sjelden videre etter en mikrobe ved pneumoni som responderer på penicillin, ettersom det ikke har noen terapeutiske konsekvenser for pasienten. Var det en annen utredning hos denne pasienten som kunne ha konsekvenser for den videre oppfølgingen? Reiseanamnesen, den atypiske kliniske presentasjonen av pneumoni og fravær av leukocytose ga grunn til å utvide de diagnostiske mulighetene.

Pasienten ble etter hvert frisk nok til utskrivning. Før avreise tok man blodprøver for serologisk analyse med tanke på Coxiella burnetii. Denne prøven viste fase 1-lgM-ogIgG-negativ, fase 2-IgM-titer på 80 (< 40) og fase 2-lgG-negativ. Prøvesvaret ble tolket som uspesifikt, og man valgte å gjenta analysen med nye prøver tatt fem uker etter symptomdebut.

Denne prøven viste fase 1-lgM-og -lgGnegativ, men fase 2-lgM 640 ( $<40$ ) og fase 2 IgG 160 (< 40). Pasienten hadde en sikker Coxiella burnetii fase 2-titerstigning og serokonversjon forenlig med akutt Q-feberinfeksjon.

\section{Diskusjon}

Q-feber er en zoonose forårsaket av Coxiella burnetii, en intracellulær gramnegativ bakterie som er til stede på alle kontinenter. De viktigste reservoarene er storfe, sau og geit, men bakterien finnes $i$ en bred gruppe dyr inkludert fugler, pattedyr og flått. Det er påvist coxiellasmitte i svenske og danske, men ikke i norske husdyrbesetninger (12). Infiserte dyr skiller ut $C$. burnetii i urin, avføring, melk og placenta (13). Den smitter vanligvis via luft, og på grunn av sin evne til å danne sporer kan den smitte over lengre avstander. Typisk er man mest utsatt for smitte på lesiden av bondegård med infiserte dyr.

Det har vært endemiske utbrudd i flere europeiske land (14). Frankrike har hatt en stigende årlig insidens av akutt Q-feber de siste 20 år, og den er nå på 2,5 per 100000 (15). Nederland hadde tidenes største utbrudd i perioden $2007-10$, men det var aldri registrert tilfeller av Q-feber før dette utbruddet (14).

I Norge har det kun vært sporadiske tilfeller, importert fra utlandet (16). Q-feber ble gjort nominativt meldepliktig til MSIS fra juli 2012, og siden da er det registrert seks tilfeller (17). Målte insidenstall for Q-feber er antatt relatert til laboratoriekvalitet, tilgjengelighet til laboratorieundersøkelser og

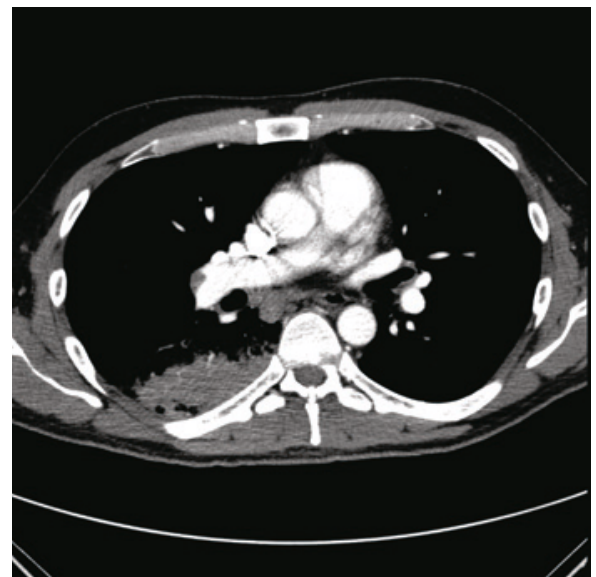

Figur 1 CT pulmonal angiografi som viser konsolidert infiltrat i høyre underlapp samt lymfeknuter i høyre hilus og mediastinum

klinikernes årvåkenhet (15). I hvilken grad Q-feber er underdiagnostisert i Norge, vites ikke, ettersom det ikke finnes studier på insidens eller prevalens.

Infeksjon med C. burnetii gir et bredt spekter av symptomer - fra asymptomatisk infeksjon (ca. $50 \%$ av tilfellene) til alvorlig endokarditt. Inkubasjonstiden er i gjennomsnitt 20 dager (fra 14 til 39) (18).

Den største kasuistikkserien av Q-feber er fransk (19). 1383 pasienter med Q-feber ble inkludert over en 14-årsperiode gjennom positive serologiske prøver. $77 \%$ av pasientene hadde akutt infeksjon - av disse hadde $40 \%$ isolert hepatitt, $20 \%$ pneumoni og hepatitt, $17 \%$ isolert pneumoni og $17 \%$ isolert feber. Det kliniske bildet varierer imidlertid mellom forskjellige geografiske områder (20). For eksempel er det sør i Spania hyppigst rapportert hepatitt, mens det i Baskerland hyppigst er rapportert pneumoni (21). I en prospektiv studie fra Baskerland med pasienter med pneumoni og karakteristika forenlig med Q-feber hadde 48 av 82 pasienter serologisk verifisert Q-feber (21). Pneumoni ved C. burnetii gir typisk feber med sparsomme fokale symptomer og blir først fanget opp ved radiologiske undersøkelser (22), slik det var tilfellet hos vår pasient.

I motsetning til pneumokokkpneumoni gir akutt Q-feber vanligvis ingen leukocytose. Økte leverenzymer ses hos ca. $85 \%$, og ca. $25 \%$ av de smittede får trombocytopeni (21). Et makulopapulært utslett kan oppstå. Akutt Q-feber gir som oftest et mildt, selvbegrensende sykdomsforløp som går over i løpet av to uker. Behandling med penicillin, som vår pasient fikk, hadde sannsynligvis ingen påvirkning på sykdommen. Ved moderat til alvorlig sykdom anbefales behandling med doksysyklin $100 \mathrm{mg} \times 2$ i to uker (23). Kinoloner har også dokumentert effekt. 


\section{RAMME 1}

Q-feber bør vurderes hos pasient med importfeber og følgende karakteristika (25):

Minst én risikofaktor for $Q$-febereksposisjon:

- Mulig kontakt med dyr

- Bosted i nærheten av bondegård

og

Akutt sykdomsbilde med en eller flere av:

- Hepatitt

- Pneumoni

- Feber

- Influensasymptomer

eller

Kronisk sykdomsbilde med en eller flere av:

- Endokarditt

- Osteomyelitt

- Infisert aortaprotese

- Aortaaneurisme

C. burnetti vokser ikke i vanlig blodkulturmedium. Diagnosen stilles ved serologisk undersøkelse eller ved nukleinsyrepåvisning. Nukleinsyrepåvisning gjøres på fullblod, serumprøve eller infisert vev (hjerteklaffer, benvev, lunger) ved Folkehelseinstituttet. Ved akutt infeksjon bør prøven tas innen to uker etter symptomdebut og før start av antibiotikabehandling (23). Serologisk undersøkelse utføres ved Fokehälsomyndigheten i Stockholm, men det er planer om å giøre analysen tilgjengelig ved Folkehelseinstiuttet i Oslo i løpet av 2016 (Siri Feruglio, personlig meddelelse).

Serokonversjon er vanligvis målbar 1-2 uker etter smitte. To uker etter infisering vil man hos $90 \%$ av pasienter med akutt Q-feberinfeksjon kunne måle antistoffer (23). Bakteriens evne til å endre antigen (antigenic shift), også kalt fasevariasjon, danner grunnlaget for å kunne skille mellom akutt og kronisk infeksjon (22). Ved akutt infeksjon vil man kun finne antistoff mot fase 2 . Ved kronisk infeksjon vil det kunne måles antistoff mot både fase 1 og fase 2. Bakterien formerer seg da $\mathrm{i}$ makrofagene.

Kronisk Q-feberinfeksjon er definert som infeksjon av mer enn seks måneders varighet. Den vanligste manifestasjonen av kronisk sykdom er endokarditt, som primært oppstår hos pasienter med forutgående klaffesykdom eller hos immunkompromitterte $(13,15)$. Kun hos $12 \%$ av pasienter med Q-feberendokarditt vil man kunne påvise vegetasjoner ved ekkokardiografi. Kronisk Q-feber vil derfor, i tillegg til å være en alvorlig sykdom, også kunne gi betydelige diagnostiske utfordringer. Det understreker viktigheten av å fange opp sykdommen tidlig i den akutte fasen, selv om sykdomsforløpet da skulle være mildt. Kronisk sykdom oppstår i kun ca. $2 \%$ av tilfellene (13). Risikofaktorer for kronisk Q-feber er, foruten forutgående klaffesykdom og svekket immunforsvar, vaskulær sykdom og graviditet.

Vår pasient hadde ingen sikre risikofaktorer for utvikling av kronisk sykdom. Da diagnosen ble stilt, hadde infeksjonen gått over. Det var da ikke indikasjon for antibakteriell behandling. Det er likevel viktig å følge opp pasienten, ettersom endokarditt kan forekomme også hos pasienter uten risikofaktorer (24). Den videre oppfølgingen vil være kontroll av serologiske prøver etter seks måneder og, dersom det er tegn til kronisk sykdom, utredning med ekkokardiografi. Kjennetegn ved Q-feber er vist i ramme 1 (25).

Pasienten har gitt samtykke til at artikkelen blir publisert.

Vi takker Mogens Jensenius for verdifulle kommentarer til manuskriptet.

\section{Lars Christian Bråten (f. 1978)}

er lege i spesialisering i indremedisin og i infeksjonssykdommer

Forfatter har fylt ut ICMJE-skjemaet og oppgir ingen interessekonflikter.

\section{Dag Henrik Reikvam (f. 1972)}

er ph.d. og spesialist i indremedisin og infeksjonssykdommer.

Forfatter har fylt ut ICMJE-skjemaet og oppgir følgende interessekonflikter: Han har mottatt foredragshonorar fra Medivir.

\section{Litteratur}

1. Mørch K, Myrvang B. Medikamentell behandling av malaria i Norge. Tidsskr Nor Legeforen 2012; 132: $664-7$.

2. World Health Organization. World Malaria Report 2014. Genève: WHO, 2014

3. Basnyat B, Maskey AP, Zimmerman MD et al. Enteric (typhoid) fever in travelers. Clin Infect Dis 2005; 41: 1467-72.

4. Berdal JE. Legionellapneumoni - viktig differen sialdiagnose ved pneumoni etter utenlandsreise. Tidsskr Nor Lægeforen 2000; 120: 3128-32.

5. Bottieau E, Clerinx J, Schrooten W et al. Etiology and outcome of fever after a stay in the tropics. Arch Intern Med 2006; 166: 1642-8.

6. Metlay JP, Schulz R, Li YH et al. Influence of age on symptoms at presentation in patients with community-acquired pneumonia. Arch Intern Med 1997: 157: $1453-9$.

7. Marrie TJ. Community-acquired pneumonia. Clin Infect Dis 1994; 18: 501-13.

8. Jartti A, Rauvala E, Kauma $\mathrm{H}$ et al. Chest imaging findings in hospitalized patients with $\mathrm{H} 1 \mathrm{~N} 1$ influenza. Acta Radiol 2011; 52: 297-304

9. Furer V, Raveh D, Picard E et al. Absence of leuko cytosis in bacteraemic pneumococcal pneumonia. Prim Care Respir J 2011: 20: 276-81.

10. Mandell LA, Wunderink RG, Anzueto A et al. Infectious Diseases Society of America/American Tho- racic Society consensus guidelines on the management of community-acquired pneumonia in adults. Clin Infect Dis 2007. 44 (suppl 2). S27-72.

11. Ziganshina LE, Titarenko AF, Davies GR. Fluoroquinolones for treating tuberculosis (presumed drug-sensitive). Cochrane Database Syst Rev 2013 6: CD004795

12. Fakta om Q-feber. Oslo: Veterinærinstituttet, 2012 www.vetinst.no/Faktabank/Q-feber (25.1.2016)

13. Hartzell JD, Wood-Morris RN, Martinez LJ et al. $Q$ fever: epidemiology, diagnosis, and treatment. Mayo Clin Proc 2008. 83: 574-9.

14. Hackert VH, van der Hoek W, Dukers-Muijrers N et al. $Q$ fever: single-point source outbreak with high attack rates and massive numbers of undetected infections across an entire region. Clin Infect Dis 2012: 55: 1591 -9

15. Frankel D, Richet $H$, Renvoisé A et al. Q fever in France, 1985-2009. Emerg Infect Dis 2011; 17: $350-6$.

16. Jensenius M, Mæland A, Kvale D et al. Q-feber importert til Norge. Tidsskr Nor Lægeforen 1997; 117: 3937-40

17. Q-feber - veileder for helsepersonell. Oslo: Statens institutt for folkehelse, 2015. www.fhi.no/ artikler/?id=82838 (25.1.2016)

18. Dupuis G. Petite J, Péter 0 et al. An important outbreak of human $Q$ fever in a Swiss Alpine valley. Int J Epidemiol 1987; 16: 282-7.

19. Raoult D, Tissot-Dupont H, Foucault C et al. Q fever 1985-1998. Clinical and epidemiologic features of 1,383 infections. Medicine (Baltimore) 2000; 79: 109-23.

20. Raoult D, Marrie T, Mege J. Natural history and pathophysiology of $Q$ fever. Lancet Infect Dis 2005 5: $219-26$

21. Sobradillo V, Zalacain R, Capelastegui A et al. Antibiotic treatment in pneumonia due to $Q$ fever. Thorax 1992; 47: 276-8.

22. Raoult D, Marrie T. Q fever. Clin Infect Dis 1995 20: $489-95$

23. Anderson A, Bijlmer H, Fournier PE et al. Diagnosis and management of $Q$ fever-United States, 2013: recommendations from CDC and the $Q$ Fever Working Group. MMWR Recomm Rep 2013; 62 (RR-03): $1-30$

24. Wielders CCH, Morroy G, Wever PC et al. Strategies for early detection of chronic Q-fever: a systematic review. Eur J Clin Invest 2013; 43: 616-39.

25. Raoult DM. Clinical manifestations and diagnosis of $Q$ fever, 2015. www.uptodate.com/contents/ clinical-manifestations-and-diagnosis-of-q-fever (25.1.2016).

Mottatt 7.4. 2015, første revisjon innsendt 6.10. 2015, godkjent 5.1. 2016. Redaktør: Liv-Ellen Vangsnes. 